\title{
Arbitrary Law Making and Unorderable Subjectivities in Legal Theoretical Approaches to Migration
}

\author{
Enrica Rigo
}

University of Roma Tre, Law Department, enrica.rigo@uniroma3.it

DOI: http://dx.doi.org/10.5324/eip.v14i2.3537

(cc) BY

This is an open access article distributed under the terms of the Creative Commons Attribution 4.0 International License, which permits unrestricted use, distribution, and reproduction in any medium, provided the original author and source are credited.

The article considers the changes that have affected European border regimes of migration control as a test case for discussing arbitrariness. The argument highlights the limited capacity of notions of arbitrariness - defined as a departure from the rule of law - to capture the ongoing conflict at the borders of Europe and instead brings the ambivalent meaning of arbitrariness to the fore.

By comparing Santi Romano's classical theory of legal pluralism with recent analyses of legal globalization processes, arbitrariness emerges either as an authoritative attempt to impose a different order on society or as a reaction to acts of resistance. In both cases, arbitrariness forcefully blurs the limits between the ordered and unordered, indicating the paradoxical impossibility of excluding the law's outside from the legal order.

On these premises, the article advocates the importance of reframing the demand for open borders as a call for freedom of those who challenge the pragmatic order of migration regimes. Indeed, arbitrariness is necessarily limited when the legal order recognizes, to an extent, the agency and the claims of subjectivities that resist the dichotomy between inclusion and exclusion.

Keywords: migration, arbitrariness, borders, legal order

The cause in the most of cases, that induce the negro to run away from service, is as much a disease of the mind as any other species of mental alienation, and much more curable, as a general rule. With the advantages of proper medical advice, strictly followed, this troublesome practice that many negros have of running away, can be almost entirely prevented, although the slaves be located on the borders of a free state, within a stone's throw of the abolitionists.

Samuel A. Cartwright (May 1851)

\section{Setting the scene of arbitrariness}

The case of Sea-Watch 3, the rescue ship captained by Carola Rackete, which broke the Italian navy's blockade of Lampedusa in order to allow the disembarkation of 
the migrants aboard, was widely reported by national and international media during the summer of 2019. In order to contextualize this episode within the discussion on arbitrary law and power, it is necessary to go back in time and describe the steps which led to the so-called policy of "closed ports" implemented by the Italian government. Already on 23 December 2018, the same humanitarian organization, Sea Watch, had rescued 32 migrants from international waters between Libya and Sicily, while a few days later, a mission operated by the nongovernmental organization (NGO) Sea Eye intercepted another boat in distress with 17 migrants on board. Contrary to the procedures foreseen by the International Convention for the Safety of Life at Sea and the International Convention on Maritime Search and Rescue (International Convention for SOLAS 1974, International Convention on Maritime SAR 1979), ${ }^{1}$ for several weeks the two vessels had not been granted a place of safety for disembarkation in a European country. The passengers were only allowed to disembark in Malta on 9 January 2019 after an agreement between eight European Union (EU) member states had been reached on the distribution of the migrants on board. A few weeks later, a similar crisis occurred off the coast of Italy, where the boat Sea-Watch 3 remained anchored for several days outside Syracuse in Sicily. ${ }^{2}$ In this second case, the European Court of Human Rights (ECHR) intervened by issuing an interim measure; however, this measure did not grant the applicants' requests to disembark but merely invited the Italian government "to take all necessary measures, as soon as possible, to provide all the applicants with adequate medical care, food, water and basic supplies as necessary" (Decision on application n. 5604/19 2019). ${ }^{3}$

The image of humanitarian vessels wandering the Mediterranean with their human cargos evokes the figure of the wolf-man used by Rudolf von Jhering to describe the bandit disenfranchised of rights and banned from the city in ancient Germanic law (Jhering 1877: 282). It is a figure that, a century later, Giorgio Agamben made famous by drawing comparisons with the condition of the Homo Sacer who is excluded from the law of the community and towards whom all others are entitled to act as sovereigns. For Agamben the outlaw condition of the werewolf marks a "threshold of indistinction and of a passage between animal and man, physis and nomos, inclusion and exclusion" (Agamben 1998: 88), and also represents the paradigm of modern sovereignty. Nonetheless, Jhering's writings on hospitality suggest that the condition of those excluded from the law, the "stranger" devoid of rights who can be killed by any member of the community, is intended to be overcome by the development of the law itself. As far back as the second half of the nineteen century, Jhering argued that "the legal capacity ${ }^{4}$ of the human being as such" had substituted the absence of rights of foreigners so that, by following this path, "the territory becomes ever smaller, while the sphere of the legal communality becomes ever greater" (Jhering 1887: 21).

Today, no one would call into question either the capacity of every person to hold rights or the legal communality instituted by international conventions and the international law of human rights. Yet the episodes sketched above pose more than one question about the alleged universality of rights when confronted with the materiality of borders and the violence faced by migrants who attempt to cross them. Should the behaviour of the vessel's migrant passengers and crew be regarded as legal/lawful or illegal/unlawful? Is the refusal or the delay in granting a place of safety for disembarkation a legitimate or an arbitrary act? 
During the crises described above, many observers spoke of a conflict between the law of the sea, which imposes a duty to save the lives of those in distress and to bring the rescued to a safe place for disembarkation, and regimes of mobility control which grant the state control over its borders. In these terms, this is a problem of legal pluralism, that is, a problem caused by multiple sets of norms with no hierarchical relationship between them. Somehow, the decision of the ECHR seems to confirm this, to the extent that it states a compromise that does not recognize either of the two legal frameworks as taking precedence over the other at least with regard to the interim measures requested. However, from the perspective of the boat passengers, what was at stake was not merely the right to disembark per se, nor the right not to suffer inhuman conditions while forced to remain moored off the coast. Indeed, for the migrants who risk their own lives attempting to cross the Mediterranean, the place (and time) of disembarkation is not at all irrelevant. Their destination is contemporary Europe, where member states' territories have not receded despite the European polity's move toward increasing legal commonality (Rigo 2007; 2008). On the one hand, human mobility, a concept which entails the how, where and when of journeys, has become one of the main areas covered by regulations that exceed national territories. On the other hand, national territories have not been replaced by a legal communality where rights are freely and equally exercised as a consequence of the capacity of every person to hold rights: instead, a series of spatial and normative limits criss-cross the space of the globalization of migration controls, up to the point that boundaries are now spread uti universi and, for a large part of the migrant and refugee population, human mobility has become a ghettoized capacity.

Positive law can give articulated answers to the two questions outlined above. With regard to the lawfulness of migrants' behaviour, collective push-backs in the open seas are not acceptable on the basis of the "non-refoulement" principle of international law, while European and national legislation grants access to asylum procedures once third-country nationals are on European territory. As a consequence, irregular entry into the territory cannot be considered an illegal act in itself. With regard to the crew's conduct, after Sea-Watch 3 was finally allowed to enter the harbour in Catania and those on board were allowed to disembark, the public prosecutor of the city issued a press release stating that neither the captain nor the crew were facing criminal charges (Procura distrettuale della Repubblica Catania 2019). ${ }^{5}$ This decision should not, however, be considered as setting a precedent. In March 2019, only a few weeks after the above crisis, the Italian flagged boat Mare Jonio, belonging to the activist group Mediterranea, disobeyed an order to stop its engine at the limit of the territorial waters of Lampedusa in Sicily. After an inspection by the Italian police, 49 migrants who had been rescued 40 miles off the Libyan coast the day before were allowed to disembark on 19 March. Nonetheless, two days later the captain and the head of mission were put under investigation and charged with smuggling. ${ }^{6}$ The order to stop the engine was given in accordance with a directive that the Italian Minister of Home Affairs, Matteo Salvini, issued after the initial rescue with the aim of preventing the Mare Jonio from entering Italian territorial waters (Direttiva per il coordinamento unificato dell'attività di sorveglianza delle frontiere marittime 2019). The directive did not introduce any specific prohibition but, rather, provided an interpretation of international conventions and national legislation according to which the passage 
of a rescue boat in territorial waters is deemed to be in conflict with national security as it aims to bring illegal migrants into national territory. As a consequence, the directive recommended that coast guards strictly follow this interpretation in order to prevent the illegal entry of migrants into domestic territory.

During the following weeks the Ministry issued two other similar directives one of which was specifically addressed to the captain and the owner of the Mare Jonio (Direttive 14100/141(8) 2019) - the lawfulness or arbitrariness of which has been debated by "experts" and observers in the media. ${ }^{7}$ In the domain of administrative law, the idea of arbitrariness as an abuse of power or deviation from the aims of the law- as in the French expression "detournement de pouvoir" - has developed in relation to that of discretion. The point is not to eliminate arbitrariness as such, but rather to limit jurisdictional control over the power of authorities and, by doing so, to reaffirm the discretional nature of power within the limit of the purposes contemplated by law (Piras 1964). Among discussions on arbitrariness, the position of the early twentieth century Italian jurist Santi Romano is emblematic of the ambivalent use of the concept. According to the author of The Legal Order:

[T] he concept of law must encompass the idea of social order. This is necessary

to eliminate all of the elements that can be reduced to mere arbitrariness [arbitrio] or material (viz. non ordered) force. Any manifestation of the law, by dint of being social, is ordered as far as its population is concerned. (Romano 2017: 12)

In Romano's view, in order to eliminate arbitrariness, seen as a material, nonordered force, the concept of law must encompass social order. Indeed, by following this view, regardless of any deviation from the aims of the law or abuse of power, an arbitrary act can be considered as the manifestation of a new specific social order. In this article the institutional theory of law developed by Romano functions as an entry point to discuss arbitrariness in relation to the contemporary transformation of borders as sites where the limit (or the limitlessness) of power is at stake. It is no coincidence that Romano's theory deeply influenced the later work of Carl Schmitt ${ }^{8}$ and his thesis that a new order had imposed its nomos on the Earth (Schmitt, 1974). Commenting on Romano's legal order theory, Schmitt affirms that a changing rule should be read as the consequence rather than the cause of a change in the legal order. The open question today is what kind of order is mirrored by the processes which are currently affecting European borders.

\section{A View from the Boundaries of Legal Order}

According to Carl Schmitt, "firm lines cannot be engraved" at sea (Schmitt 1974: 42) and for this reason, before the advent of the great sea powers, there were no limits and boundaries, no law and property on the open seas. For Schmitt, the absence of character of sea, that is, the fact that it is impossible to imprint on or engrave it, means also the absence of a unity of "order and orientation" that provides the measure of justice. The freedom of the sea shows the ambivalence that always derives from the absence of law, as "[o]ne and the same surface - which is open to all three endeavors [free fishing, peaceful navigation and unlimited warfare] - is supposed to serve both as the theater of peaceful labor and as the arena of actions consistent with a modern sea war" (Schmitt 1974: 43). In the words of the German 
legal theorist, it was only when the maritime powers - the thalassocracies - arose, that the sea was appropriated, and another outlaw figure, that of the pirate, was created:

The disturber of the order created thereby sank to the level of common criminals. The pirate was declared to be an enemy of the human race (hostis genere humani). This meant that he was ostracized and expelled, stripped of his rights, and made an outlaw by the rulers of the sea empire. (Schmitt, 1974: 44) In The Nomos of the Earth, Schmitt presents a scene that is the reverse of that sketched by Jhering. It is not the absence of law that gives rise to the outlaw but rather the "sea-appropriation", that is, the "security and order established on the sea" (Schmitt 1974: 44). In order to include the outlaw in the legal communality, it is not sufficient to shrink or enlarge territory by moving its boundaries, since it is never a merely physical or geographical "outside" that is at stake but, rather, an "outside" inscribed in the law itself.

These two different perspectives of the outlaw condition raise questions about the way in which boundaries are conceptualized in legal theory and, consequently, the way in which migration, as a quest to be admitted into a bordered community, is discussed. Critical political theory has for some time now discussed the complexity and centrality of borders and boundaries in contemporary processes of globalization and governance (Mezzadra and Neilson 2013; Balibar 2009). Still, most literature in moral and legal philosophy, when debating the legitimacy of limiting migration, does not explore the notion of boundaries but rather accepts these as contingent objects that vary under different historical and material conditions. The contingency of boundaries is assumed by seemingly very different approaches such as communitarianism, which considers boundaries vital for the sense of belonging and the fair distribution of membership, and universalism, according to which boundaries can be overcome by genuine cosmopolitanism of rights (Cole 2000; Rigo 2007). In both cases, the notion of boundaries overlaps with their historical manifestation as territorial borders and reaffirms the dichotomy between the foreign and the domestic jurisdictions of a polity (the latter variously being the nation state, a regional polity such as Europe, or a global cosmopolis). If the first account tends to essentialize the historical manifestation of territorial borders, the second fails to make sense of the persistent and increasingly common exclusion of a large share of the refugee and migrant population from the enjoyment of rights in the contemporary de-territorialized world.

In contrast to these approaches, a useful attempt to place boundaries at the centre of legal theory can be found in the recent work of Hans Lindahl $(2013 ; 2018)$. By interrogating the notion of legal space, Lindahl observes that the inside/outside divide is not only relevant to domestic and foreign jurisdictions but also indicates the reflexive distinction between "its own" and a "strange" place (Lindahl 2018: 23). From these two understandings of the legal space, it is therefore possible to draw a distinction between borders and limits: while borders - the territorial manifestation of boundaries - join and separate the domestic and the foreign, limits join and separate the "own" and the "strange". As a consequence, only borders can be considered contingent features of the territorial sphere of the validity of laws; limits are instead constitutive of all legal orders, even those that claim validity everywhere. Further, Lindahl notes that the unity of the legal space is not merely a unity of norms, but also a putative unity "qua interrelated distribution of places, times, 
subjects and act-content, which is roughly correlative to the corresponding legal system" (Lindahl 2018: 60). By adopting this standpoint, the legal space is never just a surface which materially supports one or more legal systems; rather, it emerges as "a concrete articulation of normative and physical dimensions" (Lindahl 2018: 63). This leads the author to consider the legal order as a pragmatic order which brings to the fore the perspective of those whose behaviour ought to be ordered, and the way in which they experience the legal space beyond the formal unity of a set of norms.

Not surprisingly, the problem of the "concrete and effective" unity of the legal order (Romano 2017: 5) is also central to Romano's conception which deeply influenced the work of Schmitt. For Romano:

The social order that the law brings about is not the one produced by the presence, however obtained, of norms governing social relationships. Such a social order does not exclude these norms, and indeed it uses and includes them under its scope; but at the same time it oversteps and surpasses them. This means that the law, before it is norm, before it concerns a simple social relationship, or a set of social relationships, is an organization, a structure, a position of the very society in which it develops and that this very law constitutes as a unity, as an entity in its own right (Romano 2017: 13).

The ways in which Romano and Lindahl conceive the relationship between law and society are undoubtedly different, and the outcomes to which their conceptions lead certainly diverge. While Romano tends to essentialize the normativity of social order, Lindahl's pragmatic order is explicitly conceived as a dynamic and processual ordering. Furthermore, while in the case of Romano the legal order is understood as a "self-description of society" (Teubner 2012: 21; Croce 2017: 118), Lindahl rather maintains a (putative) position for the phenomenological investigation of law and the processes of legal and social globalization. Yet, both conceptions account for a pluralistic understanding of the legal realm that complicates the view of a mere conflict between sets of norms by making room for society and by raising the issue of the unordered. In the case of the concrete and effective unity of Romano's legal order, arbitrariness - perceived as a non-ordered force - is excluded by the fact that the law necessarily encompasses the social order, thus establishing a coincidence between the two. As already highlighted, by following this route arbitrary power can be seen as the symptom of an emergent social order that, by being ordered, becomes a source of integration to the legal order itself. Lindahl's alternative perspective of pragmatic order - that is, a view from the boundaries of the legal order - likewise brings the problem of pluralism as the problem of the unordered to the foreground, but does so in a completely different way. To use the author's own words, what the conflict makes visible is not just a divergence between sets of norms, but rather a xenotopia, that is, "a place that resists accommodation in the interconnected distribution of places that a collective calls its own space" (Lindahl 2018: 38).

If the examples of the humanitarian vessels crossing the Mediterranean with their human cargos are seen through the lens of the pragmatic order, the conflict between different sets of norms - including the law of the sea, regimes of mobility control and the international law of human rights - cannot be resolved by merely repositioning their boundaries. To put it simply, the conflict would not be resolved if the international law of human rights prevailed over border regulation, since what 
is at stake is not the validity of one or the other but rather the very articulation of normative and physical dimensions within which the human capacity of mobility is exercised or marginalized: a concrete articulation and distribution of places to which both sets of norms contribute. Indeed, it is not on a blank surface nor in an empty space that these norms display themselves: as shown by the ECHR decision in the Sea-Watch 3 case, even human rights must come to terms with spatial limits, to the extent that the where, when and how of the exercising of rights is not at all irrelevant for their bearer or claimer. In other words, the fact that in the Sea-Watch case the ECHR decision could be executed without the disembarkation of the migrants contributes to the construction of a xenotopia, rather than to the integration of the boat passengers into the larger sphere of legal communality. At the same time, this is not merely the outcome of conflicting norms, but also the result of how normative and physical limits are experienced, perceived and even played against each other by those whose behaviour ought to be regulated. Undoubtedly, applicants' complaints about human rights violations were not lodged for the purpose of proving the violation per se, but rather to contest the concrete articulation of normative and physical limits imposed on migrants' mobility. This was the same articulation and distribution of place that was contested by the Mare Jonio when it entered Italian territorial waters and disobeyed the order to stop the engine (Mezzadra and Stierl 2019).

Lindahl's work does not mention Romano, and the fact that they use similar terms, such as non-ordered and unordered, may be a coincidence. Both expressions refer to the problem of the "law's outside" that constantly re-emerges not only beyond the limits of law but also as an unordered force within the law itself. Nonetheless the two expressions also reveal an important difference. While in Romano's view, the non-ordered force is either integrated into or excluded by the legal order, ${ }^{9}$ Lindahl, considering this through the lens of xenotopia, argues that it is the tension between the law and the unordered resistance to it that becomes visible. The problem of pluralism cannot be resolved as a mere conflict between different sets of norms because it involves subjects whose behaviour ought to be ordered and their acts of resistance. It is this that compels the legal order into a continuous ordering - an ordo ordinans instead of an ordo ordinatus (Lindahl 2018: 207) - and forcefully blurs the limits between the ordered and unordered, thus leaving room for the emergence of the unorderable (Lindahl 2018: 299-300). This last term, that is the unorderable, indicates anything but the paradoxical impossibility of excluding the law's outside from the legal order (see also Teubner 2006). Undoubtedly, legal systems repeatedly adopt strategies to reframe acts of contestation in a legal manner, either by authorizing or prosecuting them. Nonetheless, sometimes these acts succeed and open a space for the recognition of the unorderable within society as well as within the law. The migrants who disembarked from both the Sea-Watch 3 and the Mare Jonio ${ }^{10}$ in early 2019 succeeded in reaching Europe by contesting its borders, although they will probably experience other normative and physical limits as they continue on their journeys, thus confirming the persistence of unordered struggles for freedom of movement within Europe as well. 


\section{The Unorderable Borders of Europe}

The Mediterranean has, in recent times, been the scene of border developments that have taken place unusually quickly (Heller, Pezzani and Stierl 2018; Rigo 2018), and have not necessarily followed changes in legislation. During the Mare Nostrum military mission, which lasted from October 2013 to October 2014, search and rescue operations were conducted by Italian authorities. Official intervention was later coordinated by the European border agency, Frontex, via the Triton operation which continued until January 2018 with a focus mainly on border patrolling. The different missions of Mare Nostrum and Triton are reflected in the increased number of deaths at sea which, in 2016, reached a peak of almost 5000 on the Central Mediterranean route. Later, migrants' attempts to cross the Mediterranean decreased dramatically after Italy signed a memorandum of understanding with the Libyan Government of National Accord in February 2017. In line with this memorandum, Italy has deployed its ships in Libyan territorial waters and has supported the Libyan authorities in curbing migrant flows. ${ }^{11}$ Meanwhile, media and NGO reports have repeatedly highlighted the abuses and human rights violation that migrants suffer in official and unofficial Libyan detention camps. ${ }^{12}$

The first attempt to limit NGO rescue operations dates back to the summer of 2017, when the Italian government issued a code of conduct and invited the humanitarian organizations that operated in the Mediterranean to sign up voluntarily. ${ }^{13}$ Nonetheless, it was under the direction of the Minister of Home Affairs, Matteo Salvini, leader of the nationalistic and populist League party, that attitudes toward rescue operations hardened. Two significant breaking points involved the cases of the Aquarius and Diciotti ${ }^{14}$ ships during the summer of 2018. In June 2018, the Panamanian flagged Aquarius operated by the NGO Doctors Without Borders was not granted a place of safety for disembarkation by either Malta or Italy, and had to sail on to Spain. It is worth noting that over 100 of the 629 migrants on board had been transferred to the Aquarius by the Italian coast guard as a result of cooperation in rescue operations. Salvini publicly declared that Italian harbours were closed to boats transporting migrants, although this was never ratified in law. In August 2018, the 177 migrants who had been rescued at sea during patrolling operations were not allowed to disembark from the Diciotti, an Italian navy ship. A solution to the crisis was only reached after Ireland and Albania agreed to accept some of the migrants, thus initiating a tussle over sea borders that is still ongoing.

None of the developments outlined so far are the result of changes in legislation or decisions that followed accountable and transparent procedures. Agreements between EU member states on the distribution of migrants - sometimes involving third countries - have been informally negotiated. Needless to say, the closure of harbours and territorial waters - which also applied to Italian flagged and navy ships - should not be considered either accountable or transparent, up to the point that on two occasions the prosecutors of Catania and Rome filed investigations on the grounds of the illegitimate limitation of the freedom of the people on board. ${ }^{15}$ In light of these considerations, the management of Mediterranean borders provides a testcase for discussing arbitrariness, intended as both procedural and substantial. As a starting point, it should however be observed that arbitrariness and its synonyms are not encapsulated by any convenient single definition, and their multiple meanings "vary as the substantive legal context, with their diverging 
purposes, interests and stakes vary" (Wright 2009: 864). In line with this, I will argue that notions of arbitrariness that define it as going against reason and the rule of law fail to capture what is at stake in the conflict over European borders, and I propose instead to discuss it through the lens of an unorderable resistance to the order of borders.

Drawing on Jeremy Bentham, Timothy Endicott, for example, considers arbitrariness as a departure from reason and the rule of law:

A country is not ruled by law when it is ruled by the arbitrary-caprice - by the sweet will and whims - of executive or legislative or judicial officials. An arbitrary decision in general is one that is not distinguished, by reason in favour of it, from an unreasoned choice. In the special sense in which arbitrariness is a departure from the rule of law, a decision is arbitrary whenever the law itself ought to demand a justification other than the fact that the decision maker made it, and there is not such a justification (Endicott 2014: 18).

As recently observed by Robert Barski from the perspective of linguistic analysis, the reference to the rule of law is generally intended to exclude arbitrariness at all levels of administrative and legal decision-making processes. Arbitrariness in this sense can work only as a dysfunction of a system considered fair as a whole. However, when the law is applied and enforced in sectors such as immigration, the qualities of regularity or consistency are missing:

The rule of law standard is typically used to criticize corrupt legal systems (e.g. China, Russia or failed states), but there is a sector of law in the United States and in Europe, for example, that because of its arbitrariness, is failing to meet a standard that, outside Critical Legal Studies, is often deemed to exist. (Barski 2016: 17)

To put it simply, by defining arbitrariness as a departure from the rule of law, when it comes to migration, it is the very criterion against which it acquires its meaning that is missing. Indeed, Endicott himself indicates the reason from which arbitrariness departs as being the relevant public interests pursued by the law - that is, what Bentham would describe as "the greatest number of interests." However, migrants do not count in this number since they are excluded by the procedures which establish the rules that affect them (Benahabib 2004: 15). Moreover, when arbitrariness is defined as going against reason, as "caprice" or "sweet will and whims", it is also described as "freakish", "random" or "chosen in a lottery". In other words, it is formulated "as unsystematic in nature, dissociated from specific extralegal sources, such as race or class, that might exercise a systematic effect" (Bowers 1983: 1067). Conversely, with respect to the management of European borders and the migrants' experience of the application and enforcement of law, arbitrariness is neither random nor accidental, to the extent that it does not affect everyone who is subjected to the law in the same way. Arbitrary power is most readily used against certain categories of subjects who cannot rely on the selfrestraint that the social order imposes on officials and on society at large. Seen from this point of view, arbitrariness seems rather to blur the already slippery boundaries that differentiate it from the notion of discrimination.

Reflecting on arbitrariness in the context of the systematic effects of extralegal sources poses the problem of its identification not just in terms of the rules that regulate behaviour, but also in terms of the subjects who are affected by arbitrariness and the purposes of their actions. Access to Italian and European 
harbours is not restricted for every boat, just as border patrol missions in the Mediterranean do not act against tourist vessels. In other words, border regimes do not draw static physical and normative limits that constrain mobility indiscriminately, but rather are activated by migrants' attempts to cross borders (Bigo and Guild 2005). Nonetheless, to the extent that migrants and asylum seekers are defined by regimes of mobility control - that is, as normative categories consisting of those who attempt or succeed in crossing borders - this process of border activation hides a double fiction. On the one hand, we uncover the fiction that an "inside" and an "outside" of a territorial jurisdiction exists before the attempt to cross it; on the other, we find the fiction that legal subjectivity is abstracted from the material condition of the subject who bears it. Looking beyond these fictions, it is not human mobility as such that activates borders, nor are abstract legal subjects the target of mobility regulations. Rather, the material condition that lies beneath mobility as well as the purposes of the competing actors appear to be central components of border regulations. As shown by Mezzadra and Neilson (2013), borders do not only exclude but also include through a process of differential inclusion that in turn produces a "multiplication" of the regimes of exploitation and domination that are essential to contemporary capitalism. Although the focus of this article does not allow full exploration of this point, it is within this material perspective that both struggles for mobility and attempts to contain it must be understood.

The fact that borders are activated by those who attempt to cross them - that is, by their interests, purposes and struggles - is treated ambiguously by the law. Informal agreements for the relocation of migrants aim to circumvent the burden of hosting asylum seekers imposed by the Dublin regulation on countries of first arrival. Nonetheless, these agreements also thwart asylum seekers' attempts to reach their chosen destination or to change it according to different preferences (the official language speaks of secondary movements within the EU). Even when the right to escape from persecution, human rights abuses or wars is recognized as legitimate by international and asylum law, as well as by national and EU legislation, migrants' and refugees' determination to reach a chosen destination is usually considered capricious, and very limited discretion is recognized in respect to the agency of the claim-bearers. Here, again, the concept of arbitrariness comes to the fore in its ambivalent meaning: migrants' right to choose the where, when and how of their journeys is considered by the law as a merely arbitrary non-ordered force, to the point that responses that exceed or deviate from existing laws are justified as means to restore or prevent a violation of the order of borders.

The so-called refugee crisis, which reached a peak in 2015 , has contributed to legitimizing this framework of understanding by reconceptualizing migrants' movement as largely forced and involuntary (Rigo 2018). This view has also been endorsed by the New York Declaration for Refugees and Migrants, which called for a global approach to confronting large movements of populations and gave impetus to the subsequent (and contested) adoption of global compacts on migration and refugees (see Resolution adopted by the General Assembly of United Nations 2016). Notwithstanding the efforts of a multilateral - albeit non-binding - agreement at UN level, critical scholars have observed that the conceptualization of human mobility as mainly involuntary tends to downgrade people's entitlements from 
rights to mere needs, and to shift border policies well beyond the territorial jurisdiction of receiving countries (Vitiello 2018).

Indeed, when rights are reduced to mere needs, arbitrariness can also be easily downgraded to the procedural accomplishment of the rule of law. Going back to the earlier examples, by establishing official procedures for the distribution of migrants among member states, the transparency of disembarkment agreements would be assured, and supporters of transparency and accountability would probably be satisfied. Even the curtailment of personal liberty caused by restricting access to territorial waters could be brought under the rule of law, for example by introducing a regulation to identify and detain migrants and asylum seekers on board ship. ${ }^{16}$ These adjustments would probably satisfy rule of law advocates, but at the price of excluding from the relevant purposes of the law part of the reason underlying the conflict over the order of borders. In other words, the interests of one or more of the parties to the conflict are treated as irrelevant and thus do not affect consequential capacities from the standpoint of the law.

Global mobility control regimes constitute a legal communality that does not entail the recognition of a universal legal capacity intended to be freely and equally exercised by every subject under ordinary circumstances. The exercise of rights implies a degree of discretion in human capacities that, in the case of migrants and asylum seekers, is extremely limited. The right to mobility is of course the prime example, but all other rights, including that of habeas corpus, must "come to terms" with the interconnected distribution of place, time and capacity which defines the where, when and how of the exercising and recognition of rights (Lindahl 2018: 219). Seen from this perspective, the discretion accorded to the bearers of rights and the arbitrariness of power are inversely proportional to the extent that it is this discretion - the degree of recognition of subjective agency - that defines the extent to which a social order is "open" or "closed". From the boundaries of the legal order, the problem of arbitrariness as a non-ordered force thus emerges with a double meaning. On one side, non-ordered forces are excluded when the law and the social order coincide, and on the other side, arbitrariness is necessarily limited by discretion when the law encompasses the unordered to a certain degree, that is, when the legal order recognizes, to an extent, the claims of subjectivities that resist the dichotomy between inclusion and exclusion.

\section{Struggles for Territories, Arbitrariness and the Troublesome Practice of Migration}

Migrants' struggles are undoubtedly struggles for territories, intended as spaces of both circulation and emplacement. In the same way, the occupation of the sea by the order of borders does not correspond to a process of de-territorialization of law but rather to an extension of territories beyond their physical limit. The right to territory reveals a double meaning here: the right of every person to have a place to live on the one hand and the sovereign power of the state over its territory on the other. This is not a new debate in legal theory (Rigo 2008). At the turn of the twentieth century, the German jurist Georg Jellinek denounced the persistence of a jus sublime in territorium in the international relations between states, given that the state can only derive its right over its territory from the entitlement of citizens 
to it (Jellinek 1900: 21). Against this position, Romano was anxious to argue for the original right of the state to its territory, thus considering the latter as an essence of state personality and the violation of territory as a violation of the state itself (Romano 1902).

By shifting the focus from the instituted order of territory to the struggles that are evident at its borders, the conflict does not appear as the mere result of conflicting sets of norms, but as a conflict over the interconnected distribution of place, time and capacity which defines the where, when and how of human mobility. Against this pragmatic order, the conduct of migrants emerges as an unorderable behaviour to the extent that it actively resists the normative and physical order imposed on it (Rigo 2011). The unorderable, however, is hardly accommodated by legal theory, the central struggle of which is to redefine it in consistent terms. As noted by Lindahl (2008: 300) "[Hans] Kelsen was anxious to jettison by contrasting discretion and arbitrariness." While discussing discretion as the scope of legal power, Kelsen ends up developing the concept as a power over the scope of the law (Kelsen 2002, discussed in Lindahl 2008), thus revealing a shift in its meaning that blurs the boundaries with arbitrariness. The relationship between these two notions is reformulated by Lindahl, who asserts that "discretion as an act of instituted (or legal) power presupposes discretion as an act that institutes legal power" (Lindahl 2008: 301). Yet these are not mutually exclusive notions to the extent that one presupposes the other, although constitutional orthodoxy interprets them as disjunctive and sequential terms with a temporal linear relationship. Here, again, arbitrariness comes to the fore as a symptom of an emergent social order, either as an attempt to impose it or as an act to contain resistance against it.

This chapter does not aim to give a comprehensive account of arbitrariness in the regulation of immigration; the intention is rather to capture its problematic nature when seen from the boundaries of the legal order, that is, from the perspective of those who are excluded from the instituted scope of the law. As observed by Barski, if the politics of open borders are dismissed as naïve or hazardous dreamlands by their detractors who place the emphasis upon illegality or the absence of proper documentation among migrants, "then the broader perspective of what open borders might look like gets lost" (Barski 2016: 184). ${ }^{17}$ By bringing the question of boundaries to the fore, borders do not appear just as a contingent feature but as a concrete articulation of normative and physical limits that define the inner problem of authority - or, as articulated by Lindahl (2018: 162), "what is to count as our own in response to the challenge of the strange that stands inside and outside the legal order." When the quest for open borders is theoretically reframed as the quest for freedom of those who challenge the pragmatic order of borders, it does not appear as a merely utopian objective but rather as a course that should normatively guide a concrete politics that gives greater recognition to human mobility as a capacity entailing a degree of discretion. Indeed, the dysfunctionality that European policies have demonstrated in facing flows of migrants and asylum seekers over recent years has been mainly addressed by calling for solidarity between states in sharing the burden of refugees; conversely, solidarity among and toward migrants has been largely criminalized. A shift toward the politics of freedom of movement would instead take seriously the proposal of granting free circulation of asylum seekers within the EU, thus reducing the arbitrariness of redistribution agreements. 
Migration is mainly seen as a "troublesome practice" by decision-makers and law-makers. It is the practice of running away, but the direction in which people move or flee is in no way irrelevant or inconsequential. On 27 March 2019, a Turkish merchant vessel which had rescued 120 migrants and had been ordered to return them to Libya was diverted toward Malta by some of the survivors. Once disembarked, three youths aged 15, 16 and 19 were charged with hijacking and now face between seven and thirty years in prison. ${ }^{18}$ Although abuses against migrants in Libya have been widely reported, migrants fleeing from the country are treated as new "disturbers" of the order created in the sea by the globalization of borders. At the same time, these "disturbers" are posing a challenge to the sphere of legal communality, which in turn, might either let them sink to the level of common criminals, that is, it might condemn them to the outlaw condition, or encompass migration as a troublesome practice by recognizing that individuals have a degree of discretion in deciding the direction of their flight. In both cases what is at stake is not an act of instituted legal power but an act that institutes legal power. At stake is the choice between reaffirming and extending territorial orders and the arbitrariness of imposing new borders or recognizing the right to a place to live as a universal entitlement.

\section{Notes}

${ }^{1}$ On the legal framework of search and rescue operation, see Trevisanut (2010).

${ }^{2}$ These cases have been covered by national and international media. For an archive of press releases of the Sea-Watch organization, see https://seawatch.org/uncategorized/

3 See the ECHR's press release at https://hudoc.echr.coe.int/engpress\#\{\%22itemid\%22:[\%22003-6315038-8248463\%22]\}.

${ }^{4}$ The original German text uses the word Rechtsfähigkeit to indicate the capacity of every person to hold rights and perform juridical acts as distinguished from Handlungsfähigkeit which indicates the ability to legally act. Intended in this sense, the expression legal capacity is more faithful to the text than legal personhood.

${ }^{5}$ For a comment, see di Martino (2019). At the time of writing, the Sea-Watch 3 is anchored in the territorial waters of Lampedusa. After the rescue of 65 migrants on 15 May 2019, the captain sailed to Lampedusa, but only 18 minors and their families were allowed to disembark. The local public attorney opened a smuggling investigation and as a consequence of this decision, on 18 May the crew of the boat decided to enter territorial waters despite the interdict issued by the Ministry of Home Affairs. After more than 24 hours anchored off the coast, the seizure of the boat was ordered by the public attorney, thus leading to the disembarkation of the migrants despite disagreement by the Minister of Home Affairs.

${ }^{6}$ For Media Coverage, see Massari (2019), Fatto Quotidiano (2019).

7 The directives are not listed among typical Italian law sources, and therefore commentators even doubted their validity; for a comment, see Tani (2019).

${ }^{8}$ Together with Maurice Hauriou, Santi Romano is considered one of the principal scholars to develop an institutional theory of law during the early twentieth century. In a 1934 essay entitled Über die drei Arten des rechtwissenschaftlichen Denkens and dedicated to different types of legal thinking, Carl Schmitt openly acknowledges the importance of Romano's theory for his own understanding of the concrete legal 
order. The importance of Romano is recognized today among distinguished scholars of Global Administrative Law such as Sabino Cassese.

${ }^{9}$ This thesis is explicitly expressed in an essay in which Romano discusses the gaps in the law (Romano 1925). In contrast with the prevalent positions of the time, according to Romano matters or acts not covered by law make room for de facto liberties which are legally irrelevant, with the consequence that they lead to a negative judgment (Romano 1925: 5). Similarly, Lindahl speaks of capacities which are excluded as inconsequential (Lindahl 2018: 71).

${ }^{10}$ On 9 May 2019 the Mare Jonio rescued another 30 migrants who disembarked at Lampedusa the day after. At the time of writing, the boat is impounded and the captain has been charged with smuggling. For further updates, see https://mediterranearescue.org/.

${ }_{11}$ The memorandum has also raised the concerns of the Council of Europe's Commissioner for Human Rights (Muiznieks 2017). The memorandum is part of a broader strategy that involves African countries and includes military cooperation with Niger (AnalisiDifesa 2019).

12 For a synthesis of NGO reports, see http://protezioneinternazionale.giur. uniroma3.it/wp-content/uploads/2018/07/Rapporto-COI-Libia-detenzione-

migranti-11-maggio-2018.pdf, retrieved May 12, 2019.

${ }^{13}$ For a critical account, see the position paper ASGI (2017).

${ }^{14}$ Both cases have attracted the attention of national and international media: see for example Jones (2018), Tomasetta (2018), Tondo (2018a) and Melissari (2019).

${ }^{15}$ For media coverage, see Tondo (2018b) and Rainews (2019). At the time of writing, the Italian Senate had not authorized further investigation of the Ministry of Home Affairs in relation to the Diciotti case.

16 Procedures for the identification of migrants and asylum seekers and their channeling into different reception and legal rights systems have been introduced in the so-called 'hotspot approach' by the European Commission in order to confront exceptional migratory flows. For a critical account, see Gennari, Ferri and Caprioglio (2018), and Garelli and Tazzioli (2016).

${ }^{17}$ For a recent debate on this point, see Aksan and Bailes (2019).

${ }^{18}$ For media coverage, see Maltatoday (2019).

\section{References}

Agamben, G. (1988). The Homnibus Homo Sacer. Stanford, Stanford University Press.

AnalisiDifesa (2017, September 27). Firmato l'accordo di cooperazione militare tra Italia e Niger. AnalisiDifesa. Retrieved May 12, 2019, from http://www.analisidifesa.it/2017/09/firmato-laccordo-di-cooperazionemilitare-tra-italia e-niger/

Aksan C. and Bailes J. (2019). One Question. Open Borders, in State of Nature. Conversations on Social and Political Theory. Retrieved February 22, 2020, from https://stateofnatureblog.com/one-question-open-borders/

ASGI (2017, July 24). Position Paper on the Proposed 'Code Of Conduct For NGOs Involved In Migrants' Rescue At Sea. Retrieved May 12, 2019, from 
https://www.asgi.it/wp-content/uploads/2017/07/Draft-ASGI-PositionPaper_Final_EN.pdf

Balibar, É. (2009). 'Europe as borderland.' Environment and Planning D: Society and Space 27(2): 190-215. https://doi.org/10.1068/d13008

Balibar, É. (2003). We the People of Europe. Reflections on Transnational Citizenship. Princeton, Princeton University Press. https://doi.org/ $10.1515 / 9781400825783$

Barski, R. F. (2016). Undocumented immigrants in an Era of Arbitrary Law. The Flight and the Plight of People Deemed 'Illegal'. New York, Routledge. https://doi.org/10.4324/9781315725550

Benhabib, S. (2004). The Rights of Others: Aliens, Residents, and Citizens. Cambridge, Cambridge University Press. https://doi.org/10.1017/ CBO9780511790799

Bigo D, Guild E. (2005). Policing at a Distance: Schengen Visa Policies. In Bigo D. and Guild E. (eds.), Controlling Frontiers. Free Movement into and within Europe (pp. 233-263). Farnham: Ashgate. https://doi.org/10.4324/ 9781315259321-8

Bowers J. W. (1983). The Pervasiveness of Arbitrariness and Discrimination under Post-Furman Capital Statutes. Journal of Criminal Law and Criminology 74(3): 1067-1100. https://doi.org/10.2307/1143144

Cole, P. (2000). Philosophies of Exclusions. Liberal Political Theory and Immigration. Edinburgh, Edinburgh University Press.

Croce, M. (2017). The juristic point of view: an interpretative account of The Legal Order. Afterword. In Romano, S., The Legal Order (pp. 110-127). AbingtonNew York: Routledge.

Decision on application n. 5604/19 B.G. and Others versus Italy, 29 January 2019.

di Martino, A. (2019). Strategie comunicative di indagini penali per agevolazione dell'immigrazione irregolare. Notarelle di sociologia della comunicazione giudiziaria. Diritto Immigrazione e cittadinanza 1/2019: 1-18. https://www.dirittoimmigrazionecittadinanza.it/archivio-saggicommenti/note-e-commenti/fascicolo-2019-1/341-strategie-comunicativedi-indagini-penali-per-agevolazione-della-migrazione-irregolare-noterelledi-sociologia-della-comunicazione-giudiziaria

Direttiva per il coordinamento unificato dell'attività di sorveglianza delle frontiere marittime e per il contrasto all'immigrazione illegale ex articolo $11 \mathrm{del}$ d.lgs. n. 286/1998 recante il Testo Unico in materia di Immigrazione, Ministry of Home Affairs, 4 April 2019. Retrieved February 22, 2020, from https://www.interno.gov.it/sites/default/files/direttiva_ministro_su_controll o_frontiere_marittime_18.03.2019.pdf

Direttiva n. 14100/141(8), Ministry of Home Affairs, 4 April 2019. Retrieved February 22, 2020, from https://www.interno.gov.it/sites/default/files/ direttiva_4_aprile_2019.pdf

Direttiva n. 14100/141(8), Ministry of Home, 15 April 2019. Retrieved February 22, 2020, from http://www.interno.gov.it/sites/default/files/direttiva_del_ ministro_n._141001418_15_aprile_2019.pdf.

Endicott, T. A. O. (2014). Arbitrariness. Canadian Journal of Law and Jurisprudence/Oxford Legal Studies Research Paper 2/2014. Retrieved 
February 22, 2020, from https://ssrn.com/abstract $=2378858$ https://doi.org/10.1017/S0841820900006226

Fatto Quotidiano (2019, March 20). Migranti, indagato il comandante della Mare Jonio. Lui: "Ho salvato vite, rifarei tutto". Convalidato il sequestro. Il Fatto Quotidiano. Retrieved February 22, 2020, from https://www.ilfattoquotidiano.it/2019/03/20/migranti-indagato-ilcomandante-della-nave-mare-jonio-la-procura-convalida-ilsequestro/5050708/

Garelli, G. and Tazzioli, M. (2016). Beyond Detention: Spatial Strategies of Dispersal and Channels of Forced Transfer. Society and Space. Retrieved February 18, 2018, from https://www.societyandspace.org/articles/beyonddetention-spatial-strategies-of-dispersal-and-channels-of-forced-transfer

Gennari, L., Ferri, and F. Caprioglio, C. (2018). Dentro e oltre l'approccio hotspot. Brevi riflessioni su funzionamento e significato del sistema degli hotspot in Italia. Studi sulla Questione Criminale online. Retrieved February 18, 2018, from https://studiquestionecriminale.wordpress.com/2018/03/14/per-postfacebook/

Guerin O., (2017, September 7). Libyan migrant detention centre: 'It's like hell'. $B B C$. Retrieved May 12, 2019, from https://www.bbc.com/news/world-africa41189247

Heller, C., Pezzani L. and Stierl, M. (2018). Towards a Politics of Freedom of Movement. In Jones, R. (ed.), Open Borders: in Defence of Free Movement (chapter 3). Athens, GA: University of Georgia Press. https://doi.org/ $10.2307 /$ j.ctt $22 \mathrm{nmc} 35.8$

International Convention for the Safety of Life at Sea (SOLAS), International Maritime Organization, 1 November 1974. Retrieved February 22, 2020, from http://www.imo.org/en/about/conventions/listofconventions/pages/internat ional-convention-for-the-safety-of-life-at-sea-(solas),-1974.aspx

International Convention on Maritime Search and Rescue (SAR), 27 April 1979, Retrieved February 22, 2020, from http://www.imo.org/en/About/ conventions/listofconventions/pages/international-convention-onmaritime-search-and-rescue-(sar).aspx

Jellinek, G. (1949). La dottrina generale del diritto dello stato. Milano, Giuffrè.

Jones, S. (2018, June 17) Aquarius migrants arrive in Spain after rough week at sea. The Guardian. Retrieved February 22, 2020, from https://www.theguardian.com/world/2018/jun/17/migrant-rescue-shipaquarius-to-dock-in-spain-after-rough-week-at-sea

Kelsen, H (2002). Introduction to the Problem of Legal Theory. Oxford, Clarendon Press.

Lindahl, H. (2008). Discretion and Public Policy: Timing the Unity and Diversity of Legal Orders. In Prechal, S., and van Roermund B. (eds), The Coherence of EU law. The Search for Unity in Divergent Concepts (pp. 291-313). Oxford: Oxford University Press. https://doi.org/10.1093/acprof:oso/ 9780199232468.003.0013

Lindahl, H. (2013). Fault Lines of Globalization: Legal Order and the Politics of ALegality. Oxford, Oxford University Press. https://doi.org/10.1093/ acprof:oso/ 9780199601684.001.0001 
Lindahl, H. (2018). Authority and the Globalisation of Inclusion and Exclusion. Oxford, Oxford University Press. https://doi.org/10.1017/9781316819203

Maltatoday (2019, March 22). Three teenagers charged with hijacking commercial vessel. Maltatoday. Retrieved February 22, 2020, from https://www.maltatoday.com.mt/news/court_and_police/93980/_three_teen agers_charged_with_hijacking_commercial_vessel_\#.XlE9dC2h23X

Massari, A. (2019, March 22). Mare Jonio, Luca Casarini indagato per favoreggiamento dell'immigrazione clandestina. Il Fatto Quotidiano. Retrieved February 22, 2020, from https://www.ilfattoquotidiano.it/2019/03/ $22 /$ mare-jonio-luca-casarini-indagato-per-favoreggiamentodellimmigrazione-clandestina/5056925/

Melissari, L. (2019, September 11). Salvini e il caso Diciotti: tutto quello che c'è da sapere. TPI. Retrieved February 22, 2020, from https://www.tpi.it/ news/salvini-diciotti-caso-riassunto-20190320240933/

Mezzadra, S. and Neilson, B. (2013). Borders as Method or the Multiplication of Labor. Durham and London, Duke University Press. https://doi.org/ $10.1215 / 9780822377542$

Mezzadra S. and Stierl M. (2019). The Mediterranean battlefield of migration. Open Democracy. Retrieved April 12, 2019, from https://www.opendemocracy.net/ en/can-europe-make-it/mediterranean-battlefield-migration/

Muiznieks, N. (2017, September 28). Letter to the Italian Minister of Interior Marco Minniti Retrieved May 12, 2019, from https://rm.coe.int/letter-to-theminister-of-interior-of-italy-regarding-government-s-res/168075baea

Piras, A. (1964). Discrezionalità amministrativa. Enciclopedia del diritto. Giuffé: Milano.

Procura distrettuale della Repubblica di Catania (2019, 2 February). Comunicato stampa. Retrieved February 22, 2020, from https://www.dirittoimmigrazio necittadinanza.it/allegati/fascicolo-n-1-2019/340-comunicato-procuracatania-su-sea-watch/file

Rainews (2019, March 27). Migranti, su Sea-Watch pm Roma ipotizza sequestro persona. Rainews. Retrieved February 22, 2020, from http://www.rainews.it/dl/rainews/articoli/migranti-sea-watch-pm-romaipotizza-sequestro-persona-ea8de22e-4587-4b6b-9c1d-6f0c86883183.html

Resolution adopted by the General Assembly, United Nations, September 192016. Retrieved February 22, 2020, from https:/www.un.org/en/ga/search/ view_doc.asp?symbol=A/RES/71/1

Rigo, E. (2007). Europa di Confine. Trasformazioni della cittadinanza nell'Unione allargata. Roma, Meltemi.

Rigo, E. (2008). The Right to Territory and the Contemporary Transformation of European Citizenship. In Isin, E. F. Nyers, P. and Turner B. S. (eds.), Citizenship between past and future (pp. 150-160). New York: Routledge.

Rigo, E. (2011). Citizens despite borders: challenges to the territorial order of Europe. In Squire, V. (ed.), The contested politics of mobility: borderzones and irregularity (pp. 199-215). New York: Routledge.

Rigo, E. (2018). Migration, Knowledge Production and the Humanitarian Agenda in Times of Crisis. Journal of Modern Italian Studies 23(4): 508-521 Retrieved February 22, 2020, from https://doi.org/10.1080/1354571X.2018.1501996. 
Romano, S. (1950). Osservazioni sulla natura giuridica del territorio dello Stato. In Romano, S., Scritti minori. Vol. I. Diritto costituzionale (pp. 167-177). Milano: Giuffrè.

Romano, S. (2017). The Legal Order. Abington-New York, Routledge. https://doi.org/10.4324/9781315164519

Romano, S. (1925). Osservazioni sulla completezza dell'ordinamento giuridico. Modena, Pubblicazioni della Facoltà di Giurisprudenza della R. Università di Modena.

Schmitt, C. (2006). The Nomos of the Earth in the International Law of the Jus Publicum Europeaum. New York, Telos Press.

Tani, I. (forthcoming). Ricerca e soccorso nel Mar Mediterraneo centrale: considerazioni su alcuni recenti sviluppi. Diritto Immigrazione e cittadinanza $3 / 2019$.

Teubner, G. (2012). Constitutional Fragments: Societal Constitutionalism and globalization. Oxford, Oxford University Press. https://doi.org/10.1093/ acprof:oso/9780199644674.001.0001

Tomasetta, L. (2018, June 12). Nave Aquarius: se vi siete persi qualcosa, ecco un riassunto della vicenda dall'inizio. TPI. Retrieved February 22, 2020, from https://www.tpi.it/news/aquarius-caso-riepilogo-20180612130736/

Tondo, L. (2018a, August 21). Standoff in Italian port as Salvini refuses to let refugees disembark. The Guardian. Retrieved February 22, 2020, from https://www.theguardian.com/world/2018/aug/21/italy-refugees-salvinirefuses-coastguard-ship-docks-diciotti

Tondo, L. (2018b, August 25). Matteo Salvini formally investigated over migrant ship standoff. The Guardian. Retrieved February 22, 2020, from https://www.theguardian.com/world/2018/aug/25/matteo-salvini-formallyinvestigated-over-migrant-ship-standoff

Trevisanut, S. (2010). Search and Rescue Operations in the Mediterranean: Factor of Cooperation or Conflict? International Journal of Marine and Coastal Law: 523-542. https://doi.org/10.1163/157180810X526754

Vitiello, D. (2018). Il contributo dell'Unione Europea alla governance internazionale dei flussi di massa di rifugiati e migranti: spunti per una rilettura critica dei global compacts. Diritto Immigrazione e cittadinanza 3/2018 Retrieved February 22, 2020, from https://www.dirittoimmigrazionecittadinanza.it/archivio-saggicommenti/saggi/fascicolo-n-3-2018-1/304-saggio-vitiello/file

von Jhering, R. (1989). L'ospitalità presso gli antichi. Trani, Tipografia dell'editore E. Vecchi.

von Jhering, R. (1840). L'esprit du droit romain dans le diverses dans le diverses phases de son development. Paris, A. Marescq.

Wright, R. G. (2009). Arbitrariness: Why the Most Importance Idea in Administrative Law Can't Be Defined, and What This Means for the Law in General. University of Richmond Law Review 44: 839-865. 